\title{
Suppression of somatostatin release by duodenogastric reflux in dogs
}

\author{
W E G THOMAS, J ARDILL, AND K D BUCHANAN \\ From the Department of Surgery, Bristol Royal Infirmary, and Department of Medicine, \\ Queen's University, Belfast
}

SUMMARY The effect of duodenogastric reflux on systemic and portal venous blood concentrations of somatostatin has been studied in the dog. Duodenogastric reflux suppressed somatostatin concentrations in both systemic and portal venous blood, but this did not occur when bile alone was diverted into the stomach. The suppression was also much less marked when truncal vagotomy accompanied the reflux. These findings suggest that altered somatostatin activity may play a part in the production of the pathophysiological changes occurring in clinical conditions such as peptic ulceration, in which there is an increase in duodenogastric reflux.

Dogs with surgically produced duodenogastric reflux hypersecrete gastric acid in response to pentagastrin ${ }^{1}$ but not to histamine. ${ }^{2}$ (Table). This selective hypersecretory response is accompanied by normal fasting serum gastrin concentrations but hypergastrinaemia in response to a standard meal ${ }^{3}$ and is associated with antral gland hyperplasia. ${ }^{4}$ These changes do not occur with bile diversion alone into the stomach ${ }^{5}$ and can be abolished by the addition of truncal vagotomy. ${ }^{6}$ One possible explanation of these functional changes would be that duodenogastric reflux suppresses a naturally occurring inhibitory substance produced by the antrum, that normally suppresses gastrin release from the $G$ cells and also inhibits the acid response to pentagastrin, but not to histamine. Somatostatin fulfils these criteria and indeed a low dose infusion of $0.25 \mu \mathrm{g} / \mathrm{kg} / \mathrm{h}$ has been found to restore the functional changes seen with duodenogastric reflux down to control levels. ${ }^{7}$ The effects of such reflux have therefore been studied on the systemic and portal venous concentrations of somatostatin.

\section{Methods}

ANIMALS

Adult litter mate beagles were randomly allocated into four groups each of five animals. ${ }^{2}$

(1) A control group. (2) A group with bile diversion, achieved by ligating and dividing the

Address for correspondence: Mr W E G Thomas, FRCS, Department of Surgery, Bristol Royal Infirmary, Bristol BS2 8HW.

Received for publication 10 February 1984 common bile duct and fashioning a cholecystogastrostomy high on the lesser curvature of the stomach (Fig. 1). (3) A group with duodenogastric reflux, achieved by dividing the duodenum distal to the entry of the common bile duct and pancreatic ducts, and anastomosing the proximal end to the upper lesser curvature of the stomach. Intestinal continuity was restored by a posterior gastroduodenostomy (Fig. 1). (4) A group with duodenal reflux as above, with the addition of truncal vagotomy.

All animals were kept in the same environmental surroundings and fed on a standard diet. All animals were kept for six months postoperatively during which time secretion experiments were performed as previously described. ${ }^{1-3}$ After six months all dogs were killed, but before this, samples of portal and systemic venous blood were collected by direct puncture. All samples were assayed for somatostatin concentrations using a radioimmunoassay technique.

Blood samples were withdrawn into iced heparinised tubes, centrifuged at $4^{\circ} \mathrm{C}$ and the plasma extracted by alcohol, the extracts blown dry in a jet of air and then stored at $4^{\circ} \mathrm{C}$ pending assay. ${ }^{8}$ The samples were reconstituted before assay in $0.04 \mathrm{M}$ phosphate buffer $\mathrm{pH} \mathrm{7.4}$. The standard was synthetic cyclic somatostatin. The antibody (OB $5(1))$ was raised in rabbits to cyclic somatostatin and was used at a 1:15 000 final dilution in the assay tube. No crossreactivity with any other gut or islet peptide was found. The antibody was C-terminally directed although reaction with fragments was low, 
Table Secretory data and serum gastrin concentrations

\begin{tabular}{|c|c|c|c|c|c|c|}
\hline \multirow[b]{2}{*}{ Group } & \multicolumn{2}{|c|}{$\begin{array}{l}\text { Fasting serum gastrin } \\
\text { concentrations } \\
(p g / m l)\end{array}$} & \multicolumn{2}{|c|}{$\begin{array}{l}\text { Maximal acid output to } \\
\text { pentagastrin } 8 \mu \mathrm{g} / \mathrm{kg} / \mathrm{h} \\
(\text { mmol/30 min })\end{array}$} & \multicolumn{2}{|c|}{$\begin{array}{l}\text { Maximal acid output to } \\
\text { histamine } 80 \mu \mathrm{\mu g} / \mathrm{kg} / \mathrm{h} \\
(\mathrm{mmol} / 30 \mathrm{~min})\end{array}$} \\
\hline & Median & Range & Median & Range & Median & Range \\
\hline Control & 57 & $35-72$ & $9 \cdot 1$ & $8 \cdot 1-10 \cdot 0$ & $14 \cdot 4$ & $8 \cdot 5-18 \cdot 6$ \\
\hline Bile diversion & 60 & $42-92$ & $6 \cdot 6$ & $5 \cdot 1-9 \cdot 9$ & 11.9 & $7 \cdot 2-17 \cdot 0$ \\
\hline Duodenal reflux & 60 & $39-89$ & $15 \cdot 3$ & $13 \cdot 1-23 \cdot 9$ & $14 \cdot 5$ & $10 \cdot 7-22.9$ \\
\hline Duodenal reflux with vagotomy & 60 & $41-73$ & $4 \cdot 0$ & $2 \cdot 0-5 \cdot 2$ & $10 \cdot 9$ & $10 \cdot 0-13 \cdot 0$ \\
\hline
\end{tabular}

suggesting that the whole molecule was required for full crossreactivity. $\mathrm{N}$-tyrosylated somatostatin was iodinated by the chloramine-T technique and the iodinated peptide purified on a cation exchanger, Whatman CM52 using $0.05 \mathrm{M}$ and $0.25 \mathrm{M}$ acetate buffer. Horse serum was filtered through charcoal to remove endogenous peptides and extracted in an identical manner to the plasma samples, and added to the calibration samples to equilibrate conditions between standards and unknowns. Separation of free from antibody bound peptide was achieved by dextran coated charcoal. The assay could detect 3 $\mathrm{ng} / \mathrm{l}(\mathrm{pg} / \mathrm{ml})$ with $95 \%$ confidence. When three samples measuring mean values of $8 \mathrm{ng} / \mathrm{l}, 42 \mathrm{ng} / \mathrm{l}$ and $193 \mathrm{ng} / \mathrm{l}$ were repeatedly assayed eight times in different batches, the coefficient of variance was $10.6 \%, 5.5 \%$, and $4.4 \%$ respectively.

\section{Results}

Throughout the study, all dogs remained well, put on weight, and there was no evidence of problems with gastric emptying. The median control systemic venous somatostatin level of $20 \mathrm{pg} / \mathrm{ml}$ (range 10-45) was depressed by duodenogastric reflux down to $10.0 \mathrm{pg} / \mathrm{ml}$ (range 5-25) $(\mathrm{p}<0.05)$. This depression appeared less marked in dogs with reflux and truncal vagotomy (range $5-65 \mathrm{pg} / \mathrm{ml}$ ) and did not occur when bile alone was diverted into the stomach (range $10-50 \mathrm{pg} / \mathrm{ml}$ ) (Fig. 2).

Portal venous somatostatin concentrations were higher than in systemic venous blood (Fig. 3). Duodenogastric reflux depressed the median control level from $55.0 \mathrm{pg} / \mathrm{ml}$ (range 40-120) down to $20 \cdot 0$ $\mathrm{pg} / \mathrm{ml}$ (range 10-40) $(\mathrm{p}<0.05)$, however, and again
Bile diversion preparation

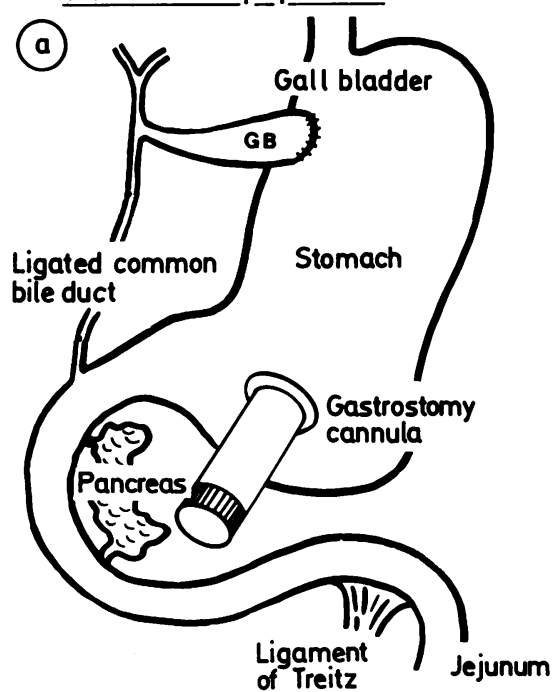

Duodenal reflux preparation

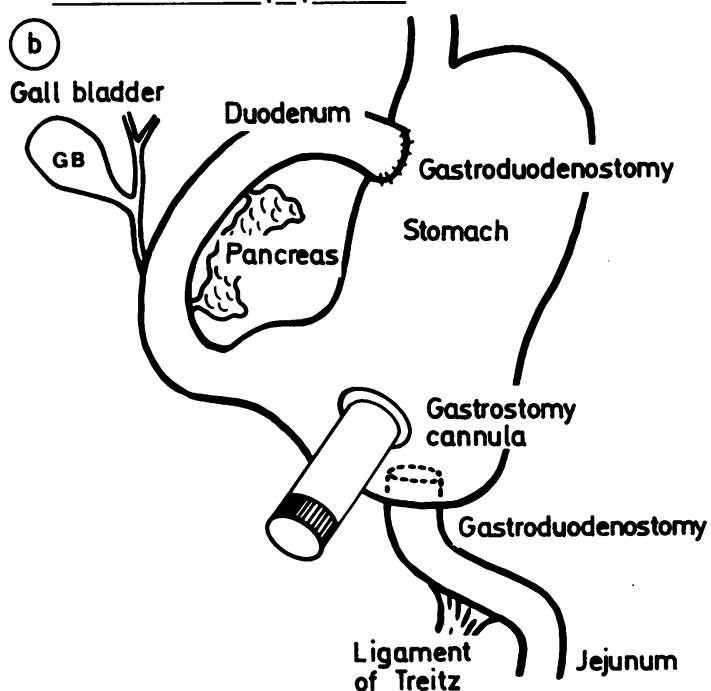

Fig. 1 (a) Bile diversion preparation. (b) Duodenal reflux preparation. 


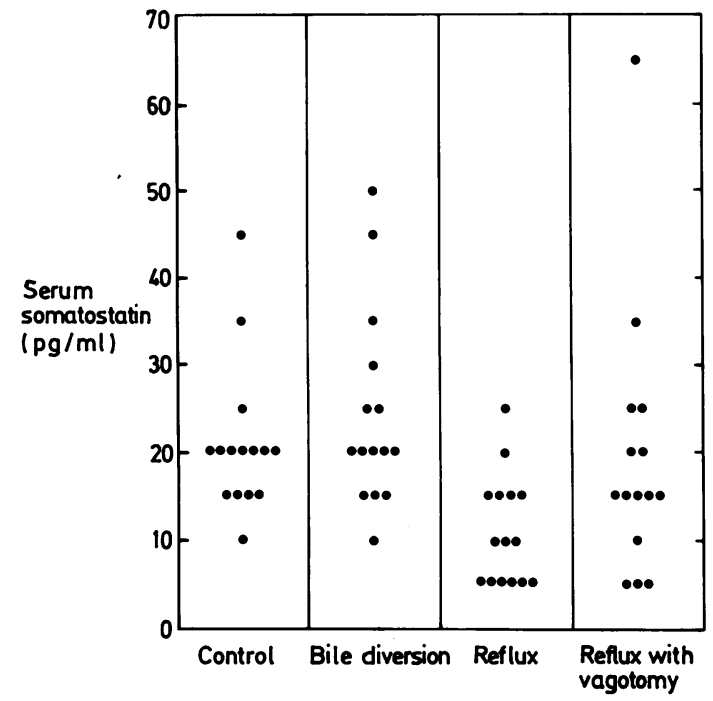

Fig. 2 Fasting systemic venous somatostatin concentrations.

this appeared less marked with the addition of truncal vagotomy (range $30-100 \mathrm{pg} / \mathrm{ml}$ ) and did not occur with bile diversion alone (range 30-140 $\mathrm{pg} / \mathrm{ml})$. Statistical analysis used the non-parametric Wilcoxon's rank sum test.

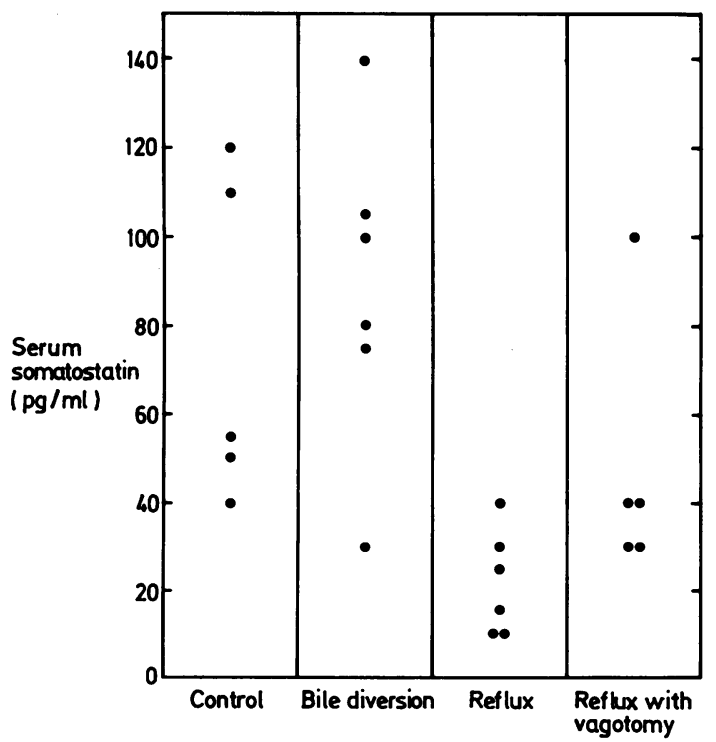

Fig. 3 Fasting portal venous somatostatin concentrations.

\section{Discussion}

The physiological role of somatostatin in the control of acid secretion remains uncertain. It is a strong inhibitor of acid secretion ${ }^{9-11}$ and gastrin release, ${ }^{710}$ however, and portal venous blood concentrations appear to respond to a change in gastric $\mathrm{pH}$. Gustavsson and Lundqvist ${ }^{12}$ showed that somatostatin levels in antral and portal venous blood of the pig fell after irrigation of the antrum with alkali, while conversely intragastric $0.1 \mathrm{M} \mathrm{HCl}$ caused degranulation of the $\mathrm{D}$ cells in the canine pyloric antrum. ${ }^{13}$ Such intragastric acid also caused a marked rise in the somatostatin concentration in antral venous blood, ${ }^{14}$ and this is reflected by a later smaller rise in somatostatin activity in the systemic venous circulation.

Suppression of somatostatin by duodenogastric reflux could therefore explain the hypersecretory state seen in these dogs. ${ }^{2}$ The nature of this suppression is unclear, however, and it does not occur with bile diversion alone and therefore appears to be a function of the addition of pancreatic juice. It therefore may not be simply a matter of alkaline reflux, but possibly an enzymic reaction or the effects of some compound formed by the combination of bile and pancreatic juice such as lysolecithin.

It is vital to exercise caution in the extrapolation of experimental findings in dogs to the clinical situation in man although the clinical relevance of these findings may be important. Increased duodenogastric reflux occurs in a wide variety of clinical conditions, but particularly in patients with gastric ulcers ${ }^{15-19}$ and to a lesser degree in those with duodenal ulcers. ${ }^{15182021}$ It has been suggested that such reflux, leading to altered somatostatin activity, is responsible for the pathophysiological changes observed in these conditions. ${ }^{22}$ The involvement of somatostatin is supported by the finding that infusions of this hormone can restore the functional changes to normal concentrations ${ }^{7}$ and also prevent the development of duodenal ulcers in cats. ${ }^{23}$ The normal ratio of $G$ to $D$ cells is $7: 1,{ }^{24}$ and this ratio can alter in some cases of duodenal ulcer, with ratios reaching 90:1 in G cell hyperplasia. Other workers report this ratio is unaltered in duodenal ulcer patients, however, ${ }^{25}$ although it does appear that antral $\mathrm{pH}$ governs the ratio of $\mathrm{G}$ and $\mathrm{D}$ cells. In spite of conflicting reports concerning these ratios, many workers have found lower antral somatostatin concentrations in patients with peptic ulcer ${ }^{26} 27$ while the D cell count may also fall in the duodenum itself. ${ }^{28} 29$

It thus appears that altered somatostatin activity may play an important part in the functional changes 
observed in patients with peptic ulcers, and the findings of this present study suggest that this altered somatostatin activity may well be secondary to duodenogastric reflux.

\section{References}

1 Thomas WEG. Gastric acid secretion in response to pentagastrin in duodenal reflux and bile diversion. $J$ Physiol 1978; 281: 36-7.

2 Thomas WEG. Functional changes in acid secretion produced by duodeno-gastric reflux. Gut 1980; 21: 413-7.

3 Thomas WEG, Lewin MR. The effect of duodenogastric reflux on serum gastrin levels in the dog. Eur Surg Res 1980; 12: 403-7.

4 Thomas WEG, Wight DGD. The histological effects on gastric mucosa of bile diversion and duodenal reflux with and without vagotomy. Br J Surg 1981; 68: 803.

5 Thomas WEG. Gastric morphological and functional changes produced by bile in the canine stomach. Eur Surg Res 1981; 13: 125-33.

6 Thomas WEG. Effect of truncal vagotomy on functional and morphological changes produced by duodeno-gastric reflux. Dig Dis Sci 1982; 27: 609-14.

7 Thomas WEG. Inhibitory effect of somatostatin on gastric acid secretion and serum gastrin in dogs with and without duodeno-gastric reflux. Gut 1980; 21: 996-1001.

8 Heding LG. Radioimmunological determination of pancreatic and gut glucagon in plasma. Diabetologia 1971; 7: 10-19.

9 Barros D'SA AAJ, Bloom SR, Baron JH. Direct inhibition of gastric acid by growth-hormone releaseinhibiting hormone in dogs. Lancet 1975; 1: 886-7.

10 Vatn MH, Scrumpf E, Hanssen KF, Myren J. The effect of somatostatin on pentagastrin stimulated gastric secretion and on plasma gastrin in man. Scand $J$ Gastroenterol 1977; 12: 833-9.

11 Thomas WEG. The kinetics of somatostatin inhibition of gastric acid secretion. Reg Peptides 1980; 1: 245-51.

12 Gustavsson S, Lundqvist G. Antral somatostatin and gastrin release. VIth World Congress of Gastroenterology 1978; 62.

13 Koybayashi S, Fujita T. Emiocytotic granule release in the basal stimulated cells of the dog induced by intraluminal application of adequate stimuli. In: Fujita $\mathrm{T}$, ed. Gastroentero-pancreatic endocrine system. Tokyo: Igaku Shoin, 1974: 49-58.

14 Schusdziarra V, Harris V, Conlon JM, Arimura A, Unger R. Pancreatic and gastric somatostatin release in response to intragastric and intraduodenal nutrients and HCL in the dog. J Clin Invest 1975; 62: 509-18.

15 Capper WM Airth GR, Kilby JO. A test for pyloric regurgitation. Lancet 1966; 2: 621-3.

16 Rhodes J, Barnardo DE, Phillips SF, Rovelstad RA, Hoffman AF. Increased reflux of bile into the stomach in patients with gastric ulcer. Gastroenterology 1969; 57: 241-52.

17 Flint FJ, Grech P. Pyloric regurgitation and gastric ulcer. Gut 1970; 11: 735-7.

18 Wormsley K. Aspects of duodeno-gastric reflux in man. Gut 1972; 13: 243-50.

19 Fisher RS, Cohen S. Pyloric sphincter dysfunction in patients with gastric ulcer. $N$ Engl J Med 1973; 288: 273-6.

20 Fiddian-Green RG, Russell RCG, Hobsley M. Pyloric reflux in duodenal ulceration and its relationship to smoking. Br J Surg 1973; 60: 321.

21 Dewar P, King R, Johnston D. Bile acid and lysolecithin concentrations in the stomach in patients with duodenal ulcer before operation and after treatment by highly selective vagotomy, partial gastrectomy, or truncal vagotomy and drainage. Gut 1982; 23: 569-77.

22 Thomas WEG. Duodeno-gastric reflux - a common factor in pathogenesis of gastric and duodenal ulcer. Lancet 1980; 2: 1166-8.

23 Konturek SJ, Radecki T, Pucher A, Coy DH, Schally AV. Effect of somatostatin on gastro-intestinal secretions and peptic ulcer production in cats. Scand $J$ Gastroenterol 1977; 12: 379-83.

24 Polak JM, Bloom SR, Bishop AE, McCrossan MV. 'D' cell pathology in duodenal ulcers and achlorhydria. Metabolism 1978; 27: (9 suppl 1) 1239-42.

25 Arnold R, Hulst MV, Neuhof $\mathrm{CH}$, Schwarting $\mathrm{H}$, Becker HD, Creutzfeldt W. Antral gastrin-producing ' $G$ ' cells and somatostatin-producing ' $D$ ' cells in different states of gastric acid secretion. Gut 1982; 23: 285-91.

26 Chayvialle JAP, Descos F, Bernard C, Martin A, Barbe C, Partensky C. Somatostatin in mucosa of stomach and duodenum in gastro-duodenal disease. Gastroenterology 1978; 75: 13-9.

27 Sumii K, Sumioka M, Matsumoto Y et al. Somatostatin in gastric mucosa and gastric juice from the normal subjects and peptic ulcer patients. Scand $J$ Gastroenterol 1982; 17: suppl 78: 531.

28 Polak JM, Bloom SR, McCrossan MV, Arimura A, Pearse AGE. Morphology of somatostatin in gastrointestinal health and disease. Gut 1976; $17: 816$.

29 Jensen SL, Beck H, Christiansen LA, Holst JJ, Amiri MS, Jensen HE. Altered concentration of somatostatin in fundic and duodenal bulb mucosa in patients with duodenal ulcer disease. Scand J Gastroenterol 1982; 17: suppl 78: 521 . 